\title{
Academic discourse semiotically re-contextualized
}

\section{A few weeks ago I read the following:}

The main theme of the works of Rushdie is the role of the writer as reader. Habermas suggests the use of subcapitalist socialism to attack class divisions. Thus, if Saussurean semiotics holds, we have to choose between postcultural discourse and the capitalist paradigm of consensus. Lyotard uses the term 'neostructuralist objectivism' to denote the bridge between sexual identity and narrativity. However, Marx's model of Saussurean semiotics implies that art serves to exploit the Other...

This text appeared in the Winter 99 issue of The Author, the journal of the Society of Authors in the UK, as a quotation within a wide-ranging round-up by the editor, Derek Parker, who noted: 'Though this reads very like a book review in one of our great literary journals, it was in fact written not by human hand (thank God! comes the cry) but was randomly generated by the Dada Engine.' This device, he added, was created by Andrew C. Bulhak of the School of Computer Science and Software Engineering at Monash University in Melbourne, Australia, and the quoted text is entirely without meaning.

However, Bulhak's Engine comes entirely too close for academic comfort. Parker's worthy piece took me back over a year, to an article in the International Herald Tribune (24 Mar 99) by the US historian Richard Pells: 'For Academics, Too, It's All in the Telling.' There he noted that, according to several recent commentators, 'most American academics write miserably', and do so on purpose, through fear of rejection and the need to conform: '[A]cademic neophytes adopt an esoteric language designed to please their mentors... They learn to use trendy post-modernist words like "discourse" and "contextualize", and to mention everything ever written about their subject.'

Pells also noted that academics 'reject the idea that a widely read book might be good.... There is no harsher epithet in a scholar's vocabulary than to call a book "journalistic".' His own view is that 'even scholarly writing is public performance, like movies and plays' and 'if scholars thought of themselves as writers, their sensitivity to their audience would intensify.' And by no means only in the US. It is a subject of worldwide communicative interest, it needs more airing, and ET would be a good place to do it in.

Tom McArthur

The editorial policy of English Today is to provide a focus or forum for all sorts of news and opinion from around the world. The points of view of individual writers are as a consequence their own, and do not reflect the opinion of the editorial board. In addition, wherever feasible, ET generally leaves unchanged the orthography (normally British or American) and the usage of individual contributors, although the editorial style of the journal itself is that of Cambridge University Press.
- Cambridge University Press 2000 No contents may be reproduced by any means without the permission of Cambridge University Press.

English Today (ISSN 0266-0784) is a quarterly.

\section{Publisher:}

Cambridge University Press,

The Edinburgh Building, Cambridge CB2 2RU, United Kingdom.

Telephone (01223) 312393 Email: journals marketing@cup.cam.ac.uk Subscriptions: the current annual subscription price for four issues for libraries and institutions is $\mathbf{f 6 1}$ outside North America; $\mathrm{f} 30$ for individuals; $\mathrm{f} 23$ for students and the retired. Prices include delivery by air where appropriate. Apply to Jane Crossland at the above address.

Advertising Sales: write to the Advertising Promoter at the above address.

USA, CANADA AND MEXICO: Publisher:

Cambridge University Press, 40 West 20th Street, New York, NY 10011-4211, USA.

Telephone (212) 9243900. Subscriptions: the current annual subscription price in USA, Canada and Mexico for libraries and institutions is $\$ 98 ; \mathbf{\$ 5 0}$ for individuals; $\$ 36$ for students and the retired. Apply to Joseph D. Hranek at the above address. Advertising Sales: write to the Advertising Coordinator at the above address.

Periodicals postage paid at New York, NY and at additional mailing offices.

POSTMASTER: send address changes in USA, Canada and Mexico to English Today, Cambridge University Press, 110 Midland Avenue, Port Chester, New York, NY 10573-4930, USA.

Japanese prices for institutions are available from Kinokuniya Company Ltd, P.O. Box 55, Chitose, Tokyo 156, Japan.

Letters to the Editor: write to Dr Tom McArthur, Editor, English Today, 22-23 Ventress Farm Court, Cherry Hinton Road, Cambridge CB1 4HD, UK. Tel 01223245934 , Fax 01223241161.

Email: Scotsway®aol.com

This journal will shortly be included in the Cambridge Journals Online service which can be found at www.journals.cup.org. For further information on other Press titles access www.cup.cam.ac.uk or www.cup.org.

Printed in the United Kingdom by the University Press, Cambridge 